
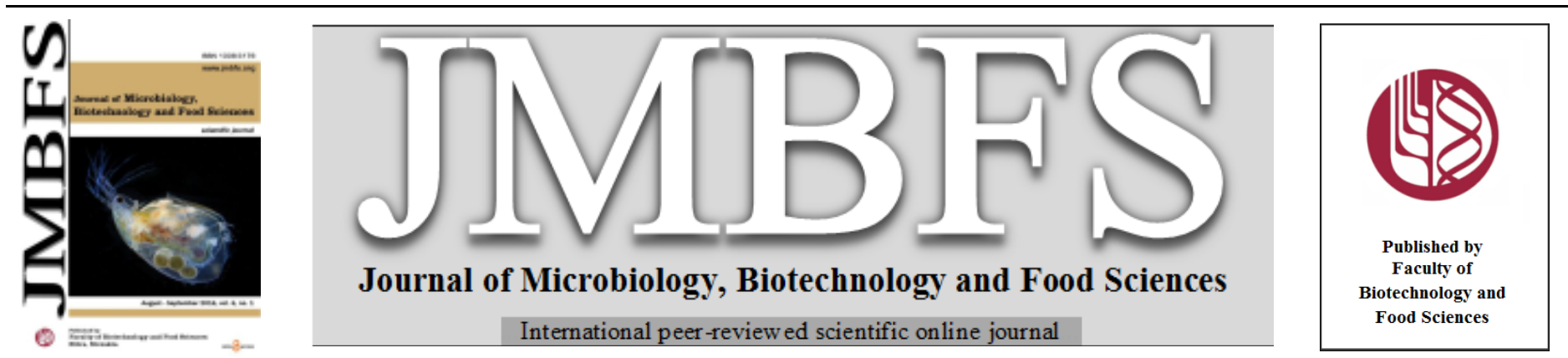

\title{
BACTERIA ASSOCIATED WITH NON-ALCOHOLIC FERMENTED BAMBOO SHOOT FOOD PRODUCT
}

\author{
Asifa Qureshi ${ }^{*}{ }^{1}$,Yogeshwari B. Itankar ${ }^{1}$, D.Saikia ${ }^{2}$, M.Mandal $^{2}$, Hemant. J. Purohit ${ }^{1}$
}

Address(es): Dr Asifa Qureshi,

1.Environmental Genomics Division, CSIR-NEERI, Nehru Marg, Nagpur 20, India.

2. Tezpur University, Assam, India.

*Corresponding author: $\underline{\text { a qureshi@ neeri.res.in }}$

doi: 10.15414/jmbfs.2016.6.1.722-729

\section{ARTICLE INFO}

Received 18.9. 2014

Revised 5. 11. 2015

Accepted 19. 4. 2016

Published 1. 8. 2016

Regular article

open $\partial_{\text {ACCESS }}$

\begin{abstract}
Pure bacterial cultures were isolated from fermented products collected from two locations of North East India (Assam and Arunachal Pradesh). Forty four variants were identified by $16 \mathrm{~S}$ rRNA gene sequencing. The dominant microbial genera found were Bacillus, Paenibacillus followed by Oceanobacillus and Lactobacillus in Assam and Bacillus, Enterococcus, Lactobacillus in Arunachal-Pradesh food products. Bacillus isolates showed extracellular enzyme production (amylases, proteases and lipases) as analyzed through plate assay. GC-MS analysis showed beneficial chemical components like organic acids, esters, aminoacids, vitamins in fermented bamboo shoot products. Probiotic attributes of culturable bacterial isolates from bamboo fermentations gives promiscuity for human consumption. Beneficial microorganisms from bamboo shoot fermented food products of North-Eastern region of India were explored and compared using bioinformatics tools.
\end{abstract}

\section{INTRODUCTION}

Bamboo shoots as food products are rich source of various macro and micro nutrients but needs processing before consumption. Fermentation is one of the processing method which increases the nutritional quality of the bamboo food product in terms of its amino acids, sugars, esters and organic acid contents (Jeyaram et al., 2008). Although fermentation is one of the oldest and most economic methods of food preservation and ethnic people of Sub-Himalayan region of North East India, especially Assam and Andhra Pradesh prepare and consume a variety of domesticated and wild bamboo tender shoots and their fermented products, there is need to increase the probiotic attributes to the food for betterment of health (Jeyaram et al., 2008, Qureshi et al., 2014). Some popular fermented bamboo tender shoots of North East India are Mesu of Sikkim, Arunachal Pradesh, Henoop, Khorisa of Assam, Hikung ,Mesu, Bastenga, Hiring of Arunachal Pradesh, Lung-siej of Meghalaya, Soibum, Soidon, Soijm of Manipur (Tamang et al., 2008). Henoop, Khorisa, Mesu, Hikung, Bastenga are traditional non-alcoholic fermented food products of Assam and Arunachal Pradesh consumed by Kharbi, Sonowal, Assamese community of Assam and Monpa, Nepali community of Arunachal Pradesh of North-East India (Das et al., 2012; Tamang et al., 2012). Fermented food products are not only rich in nutrients such as proteins, vitamins, essential amino acids, sugars, fatty acids but are also good for digestion (Jeyaram et al., 2008, Das et al., 2012).

Most of the bacterial species associated with the fermented food do not possess health risk, they are designated as GRAS (generally recognized as safe) organism (Hansen, 2002, Das et al., 2012). The objective of our study was to demonstrate culturable microbial diversity of traditionally processed fermented bamboo shoot products of Assam and Arunachal Pradesh, India using molecular approach and designate probiotic attributes of each isolate as safe and healthy food for consumption.

\section{MATERIAL AND METHODS}

Total six food samples of fermented bamboo shoot products were collected from different parts of Assam and Arunachal Pradesh in India. Out of six, three samples were from Erdangte, Khowang, North-Lakimpur, Dibrugarh locations of Assam and three samples were from Ziro, Bomdila, Bhalukpung of Arunachal Pradesh. All the samples were collected aseptically into sterile containers and transferred to the laboratory for analysis. . Fermented bamboo shoot products were prepared by defoliating and finely chopping the young edible shoots of the bamboo plant. The small pieces of bamboo shoots were placed tightly into green hollow bamboo stem and were covered with leaves of bamboo. This was then allowed to ferment at room temperature for 7-14 days. These fermented bamboo shoots were extensively used as pickles, curries and as additives in various recipes

\section{Characterisation of fermented bamboo shoot products}

\section{Microbiological analysis}

Each food product (5gms) was homogenized with $45 \mathrm{ml}$ of $1 \mathrm{X}$ PBS. It was diluted serially in the same diluents. Appropriate decimal dilution $(100 \mu l)$ of the homogenate was spread over different media plates such as Man, Rogosa and Sharpes (MRS) agar plate (Himedia), nutrient agar, 30 different media plates having different media components and incubated at $30^{\circ} \mathrm{C}$ for $24-48 \mathrm{hrs}$ Morphologically different colonies were selected and pure cultured by streaking repeatedly on respective agar media plates. The isolates were grown in respective broth and pure cultures were preserved in $30 \%$ glycerol at $-80^{\circ} \mathrm{C}$ (Sanyo, Ultralow deep freezer). The average number of microbes present per gram of different types of samples were also calculated, which was expressed in terms of CFU (colony forming units) per gram of sample (Table 1).

\section{GC-MS based metabolite profiling of fermented bamboo shoot products}

Sample preparation was carried out by modifying the method described earlier by various researchers (Ojinnaka et al., 2013, Lee et al., 2007). Fermented bamboo shoot products were finely ground in mortar and $500 \mathrm{mg}$ of the grinded samples were extracted with $5 \mathrm{ml}$ of methanol at $60^{\circ} \mathrm{C}$ in a heated water bath for $30 \mathrm{~min}$ Samples were cooled to ambient temperature for $30 \mathrm{~min}$ and then vortexed for $30-60$ seconds prior to centrifugation at $3000 \mathrm{rpm}$, at $4^{\circ} \mathrm{C}$ for $10 \mathrm{~min}$. Supernatant obtained was passed through the oven-dried anhydrous sodium sulfate. The filtrate obtained were used for GC-MS analysis.

GC-MS analysis (GC Clarus 500 Perkin Elmer system) of a food sample each from Assam and Arunachal-Pradesh was performed employing the following conditions: column Elite-1 fused silica capillary column $(30$ x $0.25 \mathrm{~mm}$ ID composed of $100 \%$ Dimethylpolysiloxane), operating in electron impact mode at $70 \mathrm{eV}$; helium (99.999\%) was used as carrier gas at a constant flow of $1 \mathrm{ml} / \mathrm{min}$ and an injection volume of $0.5 \mu \mathrm{l}$ was employed (split ratio of 10:1) injector temperature $250^{\circ} \mathrm{C}$; ion-source temperature $280^{\circ} \mathrm{C}$. The oven temperature was programmed from $150^{\circ} \mathrm{C}$ (isothermal for $2 \mathrm{~min}$ ), with an increase of $6^{\circ} \mathrm{C} / \mathrm{min}$, to $200^{\circ} \mathrm{C}$, then $5^{\circ} \mathrm{C} / \mathrm{min}$ to $300^{\circ} \mathrm{C}$, ending with a $10 \mathrm{~min}$ (isothermal at $300^{\circ} \mathrm{C}$ ). Mass 
spectra were taken at $70 \mathrm{eV}$; a scan interval of 0.5 seconds and fragments from 40 to $450 \mathrm{Da}$. Total GC running time of $50 \mathrm{~min}$. The GC-MS data was interpreted for identification of various components by comparing their retention time and mass spectra with the known component stored in the database of National Institute Standard and Technology (NIST) library having more than 62,000 patterns. The name, molecular weight and structure of the components of the test materials were ascertained (Table 2).

\section{Total dna extraction from pure bacterial culture}

The method used for the total genomic DNA extraction of 176 isolates was the modification of the method of (Jeyaram et al., 2010; Kapley et al., 2000). A single colony from the agar medium was inoculated to $5 \mathrm{ml}$ of respective broth and incubated overnight at $30^{\circ} \mathrm{C}$ in respective conditions. Culture volume of 1 OD at $600 \mathrm{~nm}$ absorbance was measured (UV-1800 Shimadzu UV/Vis Spectrophotometer) and centrifuged at $8000 \mathrm{rpm}$ for $10 \mathrm{~min}$ (Hettich Model Mikro 220R, Germany). The cell pellet was washed twice with sterile distilled water (Cascada Bio water, Pall life science) and finally resuspended in 100ul of TE buffer (Sigma) with $10 \mu \mathrm{l}$ of lysozyme $(1 \mathrm{mg} / \mathrm{ml})$ (Sigma). The cell suspension was incubated at $37^{\circ} \mathrm{C}$ for $30 \mathrm{~min}$ in constant temperature water bath (Cyber Lab) with intermediate mixing. It was then allowed to cool at room temperature. $25 \mu$ of $0.5 \mathrm{M} \mathrm{NaOH}$ was added. It was mixed gently and was incubated at room temperature for $30 \mathrm{~min}$. Then $25 \mu \mathrm{l}$ of Tris $\mathrm{pH} 7.5$ was added to it for neutralization. Finally the $345 \mu \mathrm{l}$ of sterile Milliq water was added to make up the volume to $500 \mu \mathrm{l}$. The content was gently mixed and allowed the debris to settle at the bottom at room temperature or at $4{ }^{0} \mathrm{C}$. Then the supernatant was carefully pipette out and used for PCR analysis either immediately or can be stored at $-20^{\circ}$ $\mathrm{C}$ until required.

The variation in bacterial strains was studied by RAPD (Random Amplified Polymorphic DNA) analysis. Two primers (RAPD 58, RAPD 59) were used after screening several RAPD Primers. A $50 \mu 1$ reaction mixture consisting of $5 \mu 1$ of cell free lysate with 50ng DNA, $5 \mu$ of 10X PCR Buffer, $3 \mu 1$ of $25 \mathrm{mM} \mathrm{MgCl} 2$, $5 \mu \mathrm{l}$ of $2.5 \mu \mathrm{M}$ primer(IDT), $2 \mu \mathrm{l}$ of dNTPs, $0.5 \mu \mathrm{l}$ of Taq $(5 \mathrm{U} / \mu \mathrm{l}$ ) (Applied Bioscience).The PCR reaction was carried out in Veriti thermal cycler (Applied Biosystem) through following temperature cycles: temperature profile starts with initial denaturation cycle of $5 \mathrm{~min}$ at $95^{\circ} \mathrm{C}$ followed by 35 cycles each consisting of denaturation at $94^{\circ} \mathrm{C}$ for $1 \mathrm{~min}$, annealing at $40^{\circ} \mathrm{C}$ for $1 \mathrm{~min}$, extension at $72^{\circ} \mathrm{C}$ for 2 minutes with final extension of $72^{\circ} \mathrm{C}$ for $10 \mathrm{~min}$. followed by cooling to $4^{0} \mathrm{C}$ The number of bands and their migration pattern was analyzed by agarose gel $(1.2 \%)$ electrophoresis. The gels were documented using gel documentation system. The biotypes of isolates were determined based on DNA band profiling. On the basis of RAPD profiles the bacterial strains showing highly similar banding patterns were grouped together and the strains showing different banding patterns were selected for sequencing.

\section{Identification of bacterial bsolates by 16s rDNA sequence}

16S rDNA PCR of the selected representative strains of each RAPD group were performed with universal primer 27F (5'AGAGTTTGATCMTGGCTCAG 3') and 1492R (5' TACGGYTACCTTGTTACGACTT 3'). PCR was performed using the $50 \mu \mathrm{l}$ reaction mixture consisting of 50-100ng of crude DNA, $5 \mu 1$ of $10 \mathrm{X}$ PCR buffer, $3 \mu \mathrm{l}$ of $25 \mathrm{mM} \mathrm{MgCl}_{2}, 2 \mu \mathrm{l}$ of $2.5 \mu \mathrm{M}$ primer (IDT), 2 ul of dNTPs, $0.5 \mu \mathrm{l}$ of Taq $(5 \mathrm{U} / \mu \mathrm{l})$ under the following conditions: $4 \mathrm{~min}$ initia denaturation at $95^{\circ} \mathrm{C} ; 35$ cycles of denaturation $\left(30 \mathrm{~s}\right.$ at $\left.95^{\circ} \mathrm{C}\right)$, annealing $(1 \mathrm{~min}$ at $\left.55^{\circ} \mathrm{C}\right)$, and extension $\left(2 \mathrm{~min}\right.$ at $\left.72^{\circ} \mathrm{C}\right)$; a final extension at $72^{\circ} \mathrm{C}$ for $10 \mathrm{~min}$. PCR product was purified using $1 \%$ agarose gel electrophorsis. DNA fragments were manually eluted using QIAquick PCR Purification kit (QIAGEN, Germany) and sent for sequencing using primer 27F. The resulting trimmed sequenced data were compared using BLASTN to those in the NCBI nucleotide Database. The $16 \mathrm{~S}$ rDNA sequences of representative strains of each RAPD group were aligned using Clustal X Version 2.0. with reference strains sequences obtained from NCBI database for identifying closest strain and phylogenetic relationships (Table 3 and 4).

\section{Enzyme assay and functional diversity analysis}

The purified agar medium supplemented with $10 \%$ casein and spirit blue agar supplemented with tributyrin ( $0.3 \%$ lipase substrate). Inoculated plates were allow to grow for 24-48 h. the clear zone around the colonies indicate positive results for protease and lipolytic activity respectively. For amylase activity, bacterial cultures were spotted on starch agar plates and incubated for 24-48 h before being flooded with iodine solution. Production of amylase was indicated by the existence of a clear zone around the colonies, while the rest of the plates stained blue-black.

\section{Phylogenetic tree construction}

All the sequences were compared with 16S rRNA gene sequences available in the GenBank databases by BLASTn search. Evolutionary analyses were conducted in MEGA5.2.2 (Tamura et al., 2011). Multiple sequence alignments of partial 16S
rRNA gene sequences ( $\geq 500$ bp) were carried out using CLUSTAL W (Larkin $\boldsymbol{e}$ al., 2007; Thompson et al., 1997). Phylogenetic trees were constructed in MEGA5.2.2 software from evolutionary distances obtained using Neighbor Joining and Maximum Composite Likelihood method. The robustness of the phylogeny was tested by bootstrap analysis using 1000 iterations. Accession numbers of all isolates can be viewed in respective phylogenetic tree.

\section{RESULTS AND DISCUSSION:}

Characterization of fermented bamboo food samples from assam and arunachal pradesh, India

In the present study, six fermented bamboo shoot products collected from different locations of North-East India, three each of Arunachal Pradesh and Assam were used for exploring the diverse population of bacteria. In each fermented bamboo shoot products the total viable bacterial count were in the range of $10^{4}$ cfu g-1 to $10^{5} \mathrm{cfu}$ g-1 of sample (Table.1).

Table 1 Table showing total viable bacterial count, $\mathrm{pH}$ and water activity from food samples of Assam and Arunachal Pradesh

\begin{tabular}{lcccc}
\hline Location & $\begin{array}{c}\text { Local } \\
\text { Name }\end{array}$ & $\mathbf{p H}$ & $\begin{array}{c}\text { Total viable Bacterial } \\
\text { count } \\
\text { cfu/g Sample }\end{array}$ & $\begin{array}{c}\text { Water } \\
\text { activity } \\
\text { (aW) }\end{array}$ \\
\hline Assam & Henoop & $4.5 \pm 0.2$ & $3.5 \times 10^{4}$ & 0.661 \\
& Khorisa 1 & $3.8 \pm 0.1$ & $3 \times 10^{4}$ & 0.595 \\
Arunachal & Khorisa 2 & $3.6 \pm 0.2$ & $8 \times 10^{4}$ & 0.556 \\
Pradesh & Mesu & $4.5 \pm 0.1$ & $6.8 \times 10^{5}$ & 0.598 \\
& Hikung & $4.3 \pm 0.1$ & $2.8 \times 10^{5}$ & 0.600 \\
& Bastenga & $4.8 \pm 0.2$ & $3 \times 10^{5}$ & 0.588 \\
\hline
\end{tabular}

The mean $\mathrm{pH}$ of the food sample ranged from 3 to 4.2 with Khorisa2 showing the lowest $\mathrm{pH}$ value (Table 1). This indicated that the fermented bamboo shoot products which we analyzed were acid fermented (Tamang $\boldsymbol{e t}$ al., 2008). The water activity $\left(\mathrm{a}_{\mathrm{w}}\right)$ of the fermented bamboo shoot products were found to be in the range of 0.556 to 0.661 . Less water activity signifies less possibility of foodspoilage caused by food poisoning organisms and food-borne pathogens which requires higher water activity $\left(a_{w}\right)$ for their growth (Oyewole $\&$ Isah, 2012) Protein and carbohydrate content of the fermented bamboo shoot products were found to be less than that of dry bamboo shoot indicating the presence of proteolytic and amylolytic activity during fermentation process. Also carbohydrates and proteins served as nutrients for bacterial biomass growth during fermentation.

\section{Metabolite profiling of fermented bamboo shoots using gc-ms analysis}

The fermented bamboo shoot samples of Assam and Arunachal-Pradesh were found to contain organic acids as dominant constituents followed by esters amino acids and other components (Table 2).

Organic acids: The common organic acids in the fermented bamboo shoot products of Assam and Arunachal-Pradesh were acetic acid, hexadecanoic acid and octadecanoic acid found at retention time of $2.75 \mathrm{~min}, 39.9 \mathrm{~min}$, and $34.5 \mathrm{~min}$ respectively. Also butanoic acid, propanoic acids were found common in both food samples. It has been reported that butanoic acid, propanoic acid, tetrabutyl phenyl acetate compounds were determined as major aroma compounds in Korean soy sauces and barley bran sauces (Lee et al., 2006; Choi et al., 2007; Steinhaus \& Schieberle, 2007). These compounds were used as flavor and fragrance agents in various food industries; they also provide resistance to food spoilage microorganism and thus help in preservation of food products.

Esters: During fermentation process esterification of alcohols with fatty acids leads to formation of esters. Methyl phenyl ester, linoleic acid ethyl ester, octadecanoic acid methyl ester, palmitic acid vinyl ester, ethyl esters, 2-oxo methyl ester were found to be present in the fermented bamboo shoot products of Assam and Arunachal-Pradesh. These esters are known to contribute in the characteristics pleasant aromatic and sugary flavor to the fermented food samples (Qin \& Ding, 2007; Ojinnaka \& Ojimelukwe, 2013).

Amino acids: Cystine, arginic acid, arginine, alanine, aspartic acid, aspargine, alanine were the free amino acids found in the fermented food samples. The presence of free amino acids contributes to the taste and nutritive quality of the fermented bamboo shoot products.

Other compounds found to be present in the fermented bamboo shoots are Dmannitol, $\beta$-carotene, olyl alcohol etc. which increases the nutritional quality of food (Table 2). Enzymatic saccharification and production of mannitol, sorbitol, xylitol etc carried out by amylase pro ducing Lactic acid bacteria have been reported in various studies ( Lee et al., 2012). 
Table 2 GC-MS analysis of metabolites from fermented bamboo shoot product.

\begin{tabular}{|c|c|c|}
\hline & ASSAM & ARUNACHAL PRADESH \\
\hline & Metabolites & Metabolites \\
\hline \multirow[t]{7}{*}{ Organic acids } & Acetic Acid & Acetic acid \\
\hline & 3-Deoxy-D-Mannonic acid & N-Hexadecanoic acid \\
\hline & Ethyl Malonic acid & Octadecanoic acid \\
\hline & N-Hexadecanoic acid & $\beta$-carboline-3-carboxylic acid \\
\hline & Octadecanoic acid & Adenosine-3-phosphoric acid \\
\hline & 3-Methyl Butanoic acid & \\
\hline & Propanoic acid & \\
\hline \multirow[t]{5}{*}{ Esters } & 4-Methyl phenyl ester & 4-Methyl phenyl ester \\
\hline & Linoleic acid ethyl ester & 9,12 Octadecanoic acid methyl ester \\
\hline & 9,12 Octadecanoic acid methyl ester & \\
\hline & Palmitic acid vinyl ester & \\
\hline & $\begin{array}{l}\text { 2-Oxo methyl ester } \\
\text { ethyl ester }\end{array}$ & \\
\hline \multirow[t]{4}{*}{ Amino acids } & Aspargine & Arginnic acid \\
\hline & Alanine & Cystine \\
\hline & Glycine & \\
\hline & Aspartic acid & \\
\hline \multirow[t]{4}{*}{ Other } & 2-3 Butanediol & Propylene glycol \\
\hline & 2-Amino 3-hydrooxy pyridine & 2-3 Butanediol \\
\hline & & $\beta$-Carotene \\
\hline & & D-Mannitol \\
\hline
\end{tabular}

Table 3 Bacteria identified by 16S rDNA sequence analysis from fermented bamboo shoot products of Assam and Arunachal Pradesh

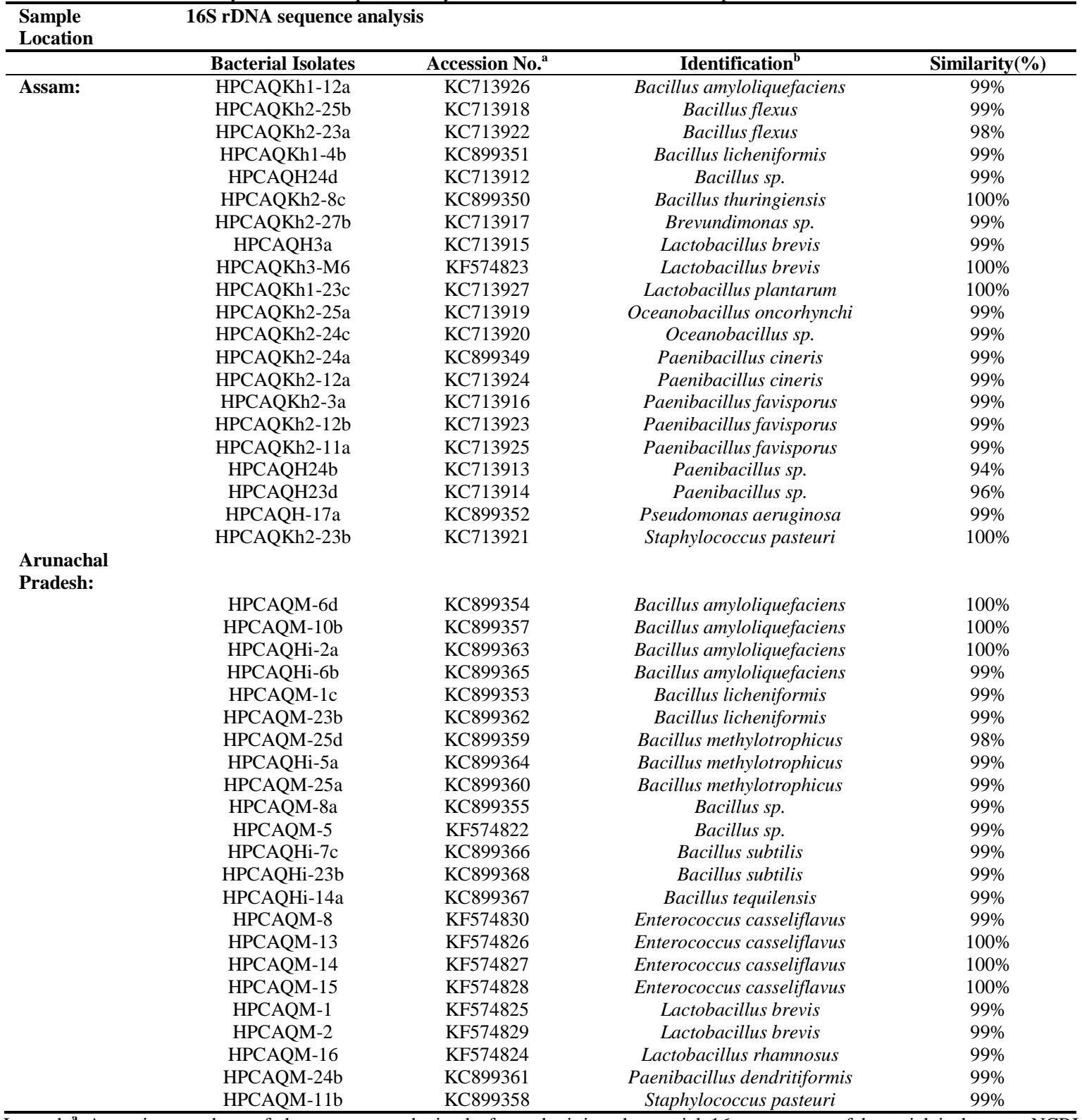

Legend ${ }^{\text {a }}$ Accession numbers of the sequences obtained after submitting the partial 16s sequences of bacterial isolates to NCBI Genebank. ${ }^{\mathbf{b}}$ Identification obtained on NCBI BLAST analysis of 16S rDNA sequence of bacterial isolates 


\section{Bacterial identification}

Based on morphological examination a total of 140 variable bacterial colonies from six fermented bamboo shoot products were isolated at random. Based on the RAPD DNA profiling and phenotypic variations 21 strains from fermented bamboo shoot products of Assam and 23 from Arunachal Pradesh were selected for further study. Total 44 isolates were subjected to $16 \mathrm{~S}$ rRNA gene sequencing and identified by BLAST analysis. 16S rRNA gene sequencing and BLAST analysis of selected strains revealed that the bacteria present in the fermented food samples of Assam belongs mainly to genera Bacilli, Lactobacilli, Staphylococcus, Oceanobacilli, Paenibacilli, Brevundimonas and that of Arunachal Pradesh belongs to Bacillus, Staphylococcus, Lactobacillus, Enterococcus, Paenibacillus (Table. 3 ).

It was also observed that all six food samples were predominated by Grampositive bacteria, with the most abundant phylum being Firmicutes (Table 4). In earlier studies, dominant species associated with fermented bamboo shoots were identified as Lactobacillus brevis. L Lactobacillus lactis, Lactobacillus fallax, Lactobacillus plantarum (Tamang et al., 2008, Qureshi et al., 2014). Our study revealed the presence of Paenibacillus cineris, Staphylococcus pasteuri, Oceanobacillus oncorhynchi, Paenibacillus favisporus, Brevundimonas sp. along with Lactobacillus brevis and Lactobacillus plantarum. The fermented bamboo shoot products of Assam showed the presence of Bacillus and Paenibacilus as the predominant bacterial genus followed by Lactobacillus. Presence of Bacilli and Paenibacilli were also reported in fermented cassava, maize, peanuts (Namrata et al., 2004). Also reports of presence of Bacillus licheniformis being a predominant species found in fermented Cauim are available (Almeida $\boldsymbol{e t}$ al. 2007). Our finding also showed presence of Bacillus licheniformis with probiotic attributes (Table 5) in both Assam and Arunachal Pradesh food samples.

Table 4 Taxonomic distribution of culturable bacterial isolates associated with fermented bamboo shoots of Assam and Arunachal Pradesh

\begin{tabular}{|c|c|c|c|c|c|c|c|}
\hline \multirow{2}{*}{$\begin{array}{l}\text { Phylogenetic } \\
\text { group }\end{array}$} & \multirow[t]{2}{*}{ Class } & \multirow[t]{2}{*}{ Genus } & \multirow[t]{2}{*}{$\mathbf{A}(21)$} & \multirow[t]{2}{*}{$\mathbf{A P}(23)$} & \multirow[t]{2}{*}{ Species } & \multirow{2}{*}{$\begin{array}{c}\text { Assam } \\
\text { (strains) }\end{array}$} & \multirow{2}{*}{$\begin{array}{c}\begin{array}{c}\text { Arunachal } \\
\text { Pradesh }\end{array} \\
\text { (strains) }\end{array}$} \\
\hline & & & & & & & \\
\hline \multirow[t]{37}{*}{ Firmicutes } & Bacillus & Bacillus & 6 & 14 & B. amyloliquefaciens & $H P C A Q K h 1-12 a$ & $H P C A Q M-6 d$ \\
\hline & & & & & B. amyloliquefaciens & & $H P C A Q M-10 b$ \\
\hline & & & & & B. amyloliquefaciens & & $H P C A Q H i-2 a$ \\
\hline & & & & & B. amyloliquefaciens & & $H P C A Q H i-6 b$ \\
\hline & & & & & B. flexus & $H P C A Q K h 2-25 b$ & \\
\hline & & & & & B. flexus & $H P C A Q K h 2-23 a$ & \\
\hline & & & & & B. licheniformis & $H P C A Q K h 1-4 b$ & $H P C A Q M-1 c$ \\
\hline & & & & & B. licheniformis & & $H P C A Q M-23 b$ \\
\hline & & & & & B. methylotrophicus & & $H P C A Q M-25 d$ \\
\hline & & & & & B. methylotrophicus & & $H P C A Q M-25 a$ \\
\hline & & & & & B. methylotrophicus & & $H P C A Q H i-5 a$ \\
\hline & & & & & B. sp. (bataviensis) & $H P C A Q H 24 d$ & \\
\hline & & & & & B. sp. (tequilensis) & & $H P C A Q M-8 a$ \\
\hline & & & & & B. subtilis & & $H P C A Q H i-7 c$ \\
\hline & & & & & B. subtilis & & $H P C A Q H i-23 b$ \\
\hline & & & & & B. tequilensis & & $H P C A Q H i-14 a$ \\
\hline & & & & & B. thuringiensis & $H P C A Q K h 2-8 c$ & \\
\hline & & & & & Bacillus sp. & & HPCAQM-5 \\
\hline & & Enterococcus & & 4 & E. casseliflavus & & $H P C A Q M-8$ \\
\hline & & & & & E. casseliflavus & & $H P C A Q M-13$ \\
\hline & & & & & E. casseliflavus & & HPCAQM-14 \\
\hline & & & & & E. casseliflavus & & HPCAQM-15 \\
\hline & & Lactobacillus & 3 & 3 & L. brevis & $H P C A Q H 3 a$ & $H P C A Q M-1$ \\
\hline & & & & & L. brevis & HPCAQKh3-M6 & $H P C A Q M-2$ \\
\hline & & & & & L. plantarum & $H P C A Q K h 1-23 c$ & \\
\hline & & & & & L.rhamnosus & & $H P C A Q M-16$ \\
\hline & & Oceanobacillus & 2 & & O. oncorhynchi & $H P C A Q K h 2-25 a$ & \\
\hline & & & & & O. sp. & $H P C A Q K h 2-24 c$ & \\
\hline & & Paenibacillus & 7 & 1 & P. cineris & $H P C A Q K h 2-24 a$ & \\
\hline & & & & & P. cineris & $H P C A Q K h 2-12 a$ & \\
\hline & & & & & P. dendritiformis & & $H P C A Q M-24 b$ \\
\hline & & & & & P. favisporus & $H P C A Q K h 2-3 a$ & \\
\hline & & & & & P. favisporus & $H P C A Q K h 2-12 b$ & \\
\hline & & & & & P. favisporus & $H P C A Q K h 2-11 a$ & \\
\hline & & & & & P. sp. & $H P C A Q H 24 b$ & \\
\hline & & & & & P. sp. & $H P C A Q H 23 d$ & \\
\hline & & Staphylococcus & 1 & 1 & S. pasteuri & $H P C A Q K h 2-23 b$ & $H P C A Q M-11 b$ \\
\hline \multirow[t]{2}{*}{ Proteobacteria } & $\begin{array}{l}\text { Alpha } \\
\text { Proteobacteria }\end{array}$ & Brevundimonas & 1 & & B. $s p$. & HPCAQKh2-27b & \\
\hline & $\begin{array}{l}\text { Gamma } \\
\text { Proteobateria }\end{array}$ & Pseudomonas & 1 & & P. aeruginosa & HPCAQH-17a & \\
\hline
\end{tabular}

Legend :Number indicates number of isolates assigned to particular genus.

: Number in bracket indicates number of isolates identified from fermented Bamboo shoots of Assam(A) and Arunachal Pradesh(AP)

The presence of Lactobacilli in bamboo shoot food samples were responsible for acidic fermentation. Lactobacillus plantarum, a known facultative heterofermenter and Lactobacillus brevis, an obligate heterofermenter produces acetic acid along with lactic acid, were found to be present in food sample of Assam and Arunachal-Pradesh. The results indicated that these food samples were mixed acid fermented product. Also the $\mathrm{pH}$ values of these food samples were in acidic range (Table. 1). The production of both the end products can prevent a food from spoilage and extend the shelf life. Acidic fermentations generally offer cost effective methods of preserving food for people in developing countries, where more sophisticated means of preservation are unaffordable and could not be used. 


\section{Screening of isolates for extracellular enzymes by plate assay}

Strains of Bacilli, Staphylococcus, Lactobacilli, Oceanobacilli, Paenibacilli, Brevundimonas, and Enterococcus were screened for their extracellular amylase, protease and lipase activity. A total of 19 isolated strains i.e. 7 from Assam and 12 from Arunachal Pradesh showed their ability to hydrolyze starch on agar plate, 20 isolates were found to show protease activity and 17 isolates showed lipase activity.

Among isolated strains of Assam, Brevundimonas sp. HPCAQKh2-27b, Paenibacillus favisporus HPCAQKh2-12b, Lactobacillus plantarum
HPCAQKh1-23c, and Bacillus amyloliquefacian HPCAQKh1-12a showed highest amylolytic activity and from Arunachal Pradesh, Bacillus licheniformi HPCAQM-1c, Bacillus amyloliquefaciens HPCAQM-10b, showed highest amylolytic activity (Table. 5). Amylolytic strains of bacterial genera Lactobacillus plantarum, Bacillus licheniformis were also isolated from Brazilian fermented food (Almeida et al., 2007) and Nigerian fermented food (Johansson et al., 1995; Sanni 2002). The amylolytic activity was responsible for hydrolysis of starch during Bamboo shoot fermentation.

Table 5 Amylase, Protease and Lipase activity of bacterial species isolated from fermented bamboo shoot products of Assam and Arunachal Pradesh.

\begin{tabular}{|c|c|c|c|c|}
\hline Location & Bacterial Isolates & Amylase & Protease & Lipase \\
\hline \multirow[t]{11}{*}{ Assam } & Bacillus amyloliquefaciens HPCAQKh1-12a & ++ & - & - \\
\hline & Bacillus flexus HPCAQKh2-23a & - & + & - \\
\hline & Bacillus flexus HPCAQKh2-25b & - & + & - \\
\hline & Bacillus thuringiensis HPCAQKh2-8c & + & +++ & + \\
\hline & Brevundimonas sp. HPCAQKh2-27b & ++ & - & + \\
\hline & Lactobacillus brevis HPCAQH3a & - & ++ & + \\
\hline & Lactobacillus plantarum HPCAQKh1-23c & ++ & + & - \\
\hline & Paenibacillus cineris HPCAQKh2-12a & + & - & - \\
\hline & Paenibacillus favisporus HPCAQKh2-12b & ++ & ++ & ++ \\
\hline & Paenibacillus favisporus HPCAQKh2-3a & + & - & - \\
\hline & Pseudomonas aeruginosa HPCAQH-17a & - & - & + \\
\hline \multicolumn{5}{|c|}{ Arunachal Pradesh } \\
\hline & Bacillus amyloliquefaciens HPCAQHi-6b & ++ & ++ & + \\
\hline & Bacillus amyloliquefaciens HPCAQHi-2a & ++ & +++ & + \\
\hline & Bacillus amyloliquefaciens HPCAQM-1-b & +++ & +++ & ++ \\
\hline & Bacillus amyloliquefaciens HPCAQM-6d & ++ & +++ & + \\
\hline & Bacillus licheniformis HPCAQM-1c & +++ & ++ & - \\
\hline & Bacillus licheniformis HPCAQM-23b & + & + & + \\
\hline & Bacillus methylotrophicus HPCAQHi-5a & ++ & +++ & + \\
\hline & Bacillus methylotrophicus HPCAQM-25a & + & + & + \\
\hline & Bacillus methylotrophicus HPCAQM-25d & - & ++ & - \\
\hline & Bacillus sp. HPCAQM- $8 a$ & ++ & ++ & + \\
\hline & Bacillus subtilis HPCAQHi-23b & + & ++ & + \\
\hline & Bacillus subtilis HPCAQHi-7c & ++ & ++ & + \\
\hline & Bacillus tequilensis HPCAQHi-14a & ++ & +++ & + \\
\hline & Enterococcus casseliflavus HPCAQM13 & - & - & + \\
\hline & Staphylococcus pasteuri HPCAQM-2b & - & + & - \\
\hline
\end{tabular}

Proteolytic enzyme assay revealed that there was appreciable difference in protease activity among the strains identified. The protease secreting ability of genus Bacillus have been well known (Nascimento \& Martin 2004; Beg and Gupta 2003) and we found total six strains showing highest protease activity indicated by a zone of clearance of more than $150 \mathrm{~mm}$. In general Lactobacill showed low protease activity. Low protease activity of Lactobacilli have been reported in fish fermentation also by Namrata et al., 2004. Reports showing both amylase and protease activity of Lactobacilli was also available (Thapa $\boldsymbol{e t}$ al., 2006)

Lipolytic activity was found comparatively less than the amylase and protease activity. Total 17 isolated strains showed liypolytic activity. Paenibacillus favisporus HPCAQKh2-12b strain showed highest lipolytic activity (zone of clearance more than $100 \mathrm{~mm}$ ).

Amylolytic, proteolytic and lipolytic properties of fermenting microorganism may be important for degradation of starch (which determines the availability of free sugars), proteins(which determines the availability of essential amino acids and lipids (which determine the availability of short-chain fatty acids in particular). These properties may have considerable effects on the taste and flavor of fermented food products. Strains isolated from Arunachal Pradesh showed comparatively higher enzyme activity than that of Assam although both the regions belong to North-East India (Table. 5).
Bacteria isolated in this study were found to possess extracellular enzyme activity (amylases, proteases, lipases) which were responsible for the breakdown of raw organic molecules (polymers) resulting into accumulation of certain byproducts of smaller molecular weights, which may improve the organoleptic and nutritional quality of food products.

\section{Phylogenetic analysis}

Phylogenetic tree based on 16s rRNA gene sequences placed the 21 isolates of Assam into 2 major groups viz; Firmicutes and Proteobacteria and Arunachal Pradesh into single group Firmicutes. The major cluster Firmicutes were further divided into smaller sub-clusters of Paenibacilli, Bacilli, Oceanobacilli, Staphylococcus, Lactobacilli. The genus Bacillus (Firmicutes) represented the major group in food samples of both the location (Fig 1, Fig 2). In Assam sample dominant population was represented by the genus Paenibacillus followed by the genus Bacilli and then by Lactobacilli and Oceanobacilli while in Arunachal Pradesh food samples Bacillus was the only genus found to be dominant. 
27

Bacillus amyloliquefaciens HPCAQM-10b KC899357 Bacillus amyloliquefaciens HPCAQHi-6b KC899365

Bacillus amyloliquefaciens HPCAQHi-2a KC899363

27 Bacillus amyloliquefaciens HPCAQM-6d KC899354

Bacillus amyloliquefaciens NBRC15535 NR 041455.1

Bacillus methylotrophicus Kharuss0103KC424493.1

Bacillus methylotrophicus HPCAQM-25d KC899359

Bacillus methylotrophicus HPCAQM-25a KC899360

47 Bacillus methylotrophicus HPCAQHi-5a KC899364

Bacillus subtilis HPCAQHi-7c KC899366

33 Bacillus subtilis LB-01 AB201120.1

Bacillus subtilis HPCAQHi-23b KC899368

- Bacillus licheniformis HPCAQM-1c KC899353

100

Bacillus licheniformis HPCAQM-23b KC899362

Bacillus licheniformis ATCC14580 NR 074923.1

86 Bacillus sp. HPCAQM-8a KC899355

Bacillus sp. HPCAQM5 KF574822

Bacillus tequilensis HPCAQHi-14a KC899367

Bacillus tequilensis MML2 JX847616.1

100 Staphylococcus pasteuri HPCAQM-11b KC899358

Staphylococcus pasteuri ATCC51129 NR 024669.1

Bacillus cereus ATCC14579 NR 074540.1

68

Bacillus thuringiensis IAM12077 NR 043403.1

100

Enterococcus casseliflavus HPCAQM13 KF574826

Enterococcus casseliflavus HPCAQM15 KF574828

100

Enterococcus casseliflavus HPCAQM8 KF574830

Enterococcus casseliflavus strain FMAC98 KF060255.1

Enterococcus casseliflavus HPCAQM14 KF574827

100 Lactobacillus rhamnosus HPCAQM-16 KF574824

Lactobacillus rhamnosus strain G (ATCC 53103) NR 102778.1

Lactobacillus plantarum WCFS1 NR 075041.1

95

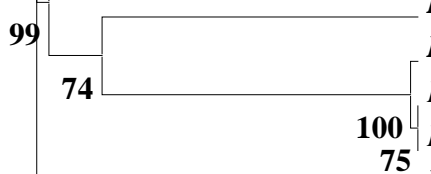

Lactobacillus brevis ATCC 367 strain NR 075024.1

Lactobacillus brevis HPCAQM1 KF574825

75

Bacillus firmus IAM12464 NR 025842.1

100 Paenibacillus dendritiformis HPCAQM-24b KC899361

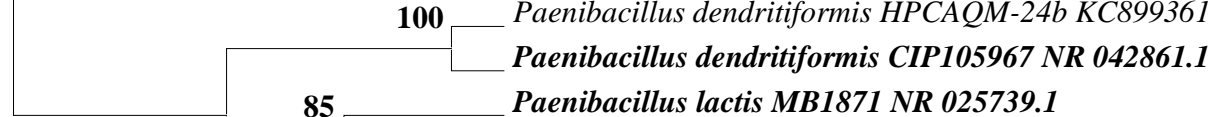

Paenibacillus lactis MB1871 NR 025739.1

Paenibacillus lautus JCM9073 NR 040882.1

Paenibacillus cineris LMG18439 NR 042189.1

Paenibacillus favisporus GMP01 NR 029071.1

100

Pseudomonas aeruginosa PAO1 NR 074828.1 Brevundimonas intermedia ATCC15262 NR 041966.

\section{Outgroup}

$\begin{array}{llllll}0.10 & 0.08 & 0.06 & 0.04 & 0.02 & 0.00\end{array}$

Figure 1 Phylogenetic relationship of Arunachal-Pradesh isolates: based on the partial 16S rDNA sequences of representative isolates generated using the NeighborJoining method in MEGA5. The reference sequences were obtained from NCBI database are indicated in bold 


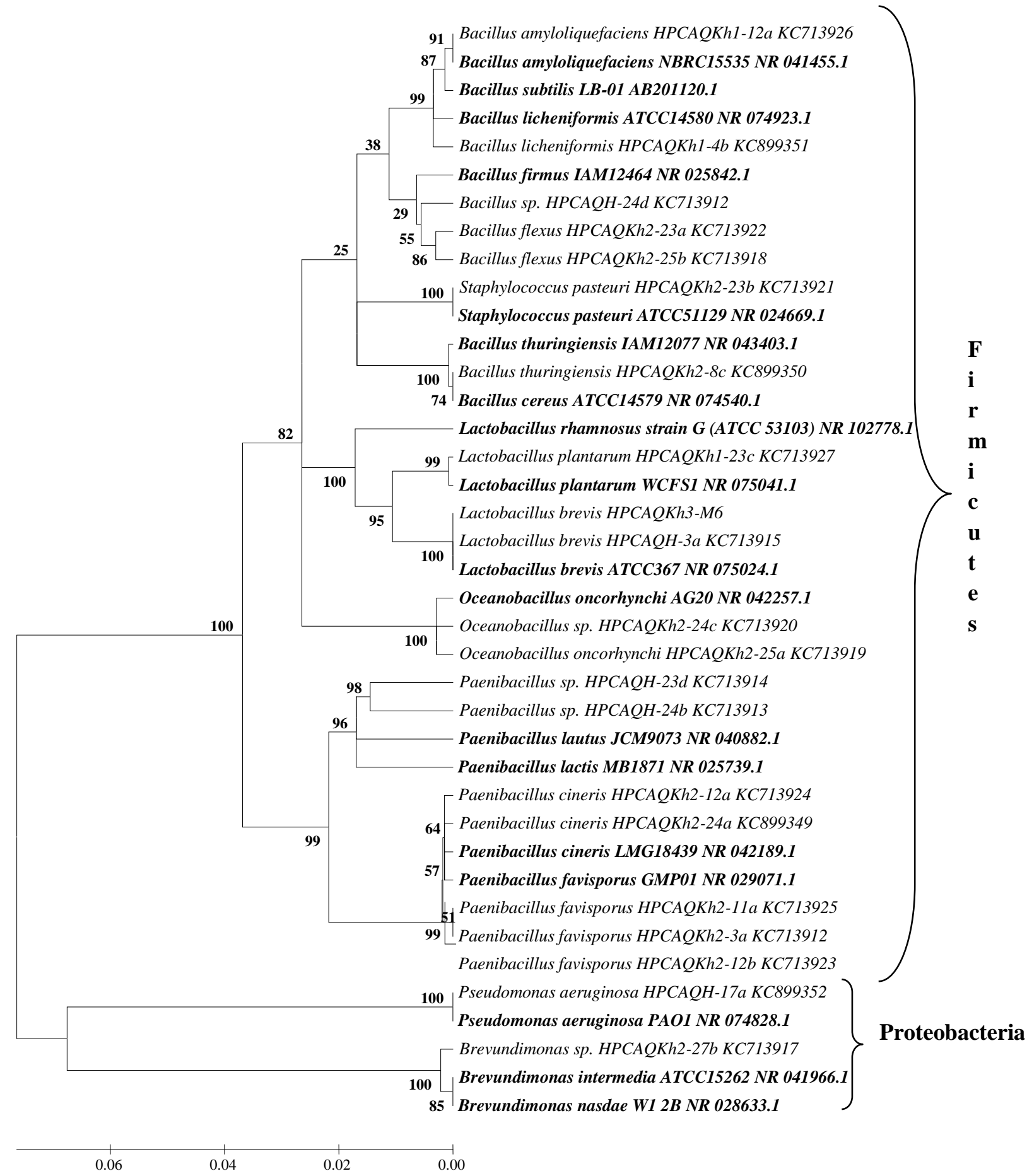

Figure 2 Phylogenetic relationship of Assam isolates: based on the partial 16S rDNA sequences of representative isolates generated using the Neighbor-Joining method in MEGA5.2.2. The reference sequences were obtained from NCBI database are indicated in bold.

\section{CONCLUSION}

The culturable bacterial diversity of non-alcoholic bamboo shoot fermented food products of North East India (Assam and Arunachal Pradesh) by using molecular tool like $16 \mathrm{~S}$ rDNA sequencing were envisaged. The dominant microbial genera found in Arunachal-Pradesh food products were Bacillus, Paenibacillus, Oceanobacillus and Lactobacillus. However in Assam Enterococcus were present additionally. Mainly Bacillus species from both the locations showed extracellular enzyme activity (amylases, proteases and lipases) which added to the probiotic attribute of the food along with the beneficial metabolites like esters and amino acids. The results infer to provide idea for formulating the functional starter cultures for large scale bamboo fermentations for food industries.
Acknowledgement: Authors of the manuscript thank Director, CSIR-NEERI (Council of Scientific and Industrial Research - National Environmental Engineering Research Institute), Nagpur, India for providing the required facilities for carrying out this work and DBT (Department of Biotechnology) for funding under DBT's Twinning Program for North Eastern Regions (NER) of India.

\section{REFERENCES}

ALMEIDA, E.G., RACHID, C.C., SCHWAN, R.F. 2007. Microbial population present in fermented beverage 'cauim' produced by Brazilian Amerindians. International Journal of Food Microbiology, 120, 146-51. http://dx. doi.org/ $\underline{10.1016 / j . j \text { ijfoodmicro.2007.06.020 }}$ 
BEG, Q.K., \& GUPTA, R., 2003. Purification and characterization of an oxidation-stable, tiol-dependent serine alkaline protease from Bacillus mojavensis. Enzyme and Microbial Technology, 32, 294-304

CHOI, U. K., KIM, M. H., KWON, O. J., LEE, T. J., \& LEE, N. H. 2007. Characterization of aroma components in barley bran sauce using statistical analysis. Food Science Biotechnoogy, 16, 23-28.

CHOUDHURY, D., SAHU, J.K., SHARMA, G.D. 2012. Bamboo shoot: Microbiology, Biochemistry and Technology of fermentation - a review. Indian Journal of Traditional Knowledge, 11, 242-249.

DAS, A. J. AND DEKA, S. C. 2012. MiniReview: Fermented foods and beverages of the North-East India. International Food Research Journal, 19 Issue $2,377$.

HANSEN, E. B. 2002. Commercial bacterial starter cultures for fermented foods of the future. International Journal of Food Microbiology, 78, 119-131.

JEYARAM, K., MOHENDRO SINGH, W., PREMARANI, T., DEVI, A.R., CHANU, K.S., TALUKDAR, N.C., SINGH, M.R. 2008. Molecular identification of dominant microflora associated with 'Hawaijar' - a traditional fermented soybean (Glycine max (L.)) food of Manipur, India. International Journal of Food Microbiology, 122, 259-68.

JEYARAM, K., ROMI, W., TH. ANAND SINGH, RANJITA DEVI, A., SONI DEVI, A. 2010. Bacterial species associated with traditional starter cultures used for fermented bamboo shoot production in Manipur state of India. International Journal of Food Microbiology, 143, 1-8. http://dx. doi.org/ 10.1016/j.ijfoodmicro.2010.07.008

JOHANSSON, M.L., SANNI, A., LONNER, C., MOLIN,G. 1995 Phenotypically-based taxonomy using API $50 \mathrm{CH}$ of Lactobacilli from Nigerian Ogi, and the occurrence of starch fermenting strains. International Journal of Food Microbiology, 25, 159-168. http://dx.doi.org/10.1016/0168 1605(94)00096-O

KAPLEY, A., LAMPEL, K., PUROHIT, H.J., 2000. Development of duplex PCR for Salmonella and Vibrio. World Journal of Microbiology Biotechnology, 16, 457- 458. http://dx.doi.org/ 10.1023/A:1008924119825

LARKIN, M.A., BLACKSHIELDS, G., BROWN, N.P., CHENNA, R., MCGETTIGAN, P.A., MCWILLIAM, H., VALENTIN, F., WALLACE I.M., WILM, A., LOPEZ, R., THOMPSON, J.D., GIBSON, T.J. AND HIGGINS, D.G. 2007. Clustal W and Clustal $\mathrm{X}$ version 2.0. Bioinformatics, 23 (21): 2947-2948.

LEE, S. M., SEO, B. C., \& KIM, Y. S. 2006. Volatile compounds in fermented and acid-hydrolysed soy sauces. J. Food Sci., 71, C146-C156. http://dx. doi.org/ 10.1111/i.1365-2621.2006.tb15610.x

LEE, YUN, S.,, KIM, H. Y., LEE, S., LEE, J. M., MUTHAIYA, M. J., KIM, B. S., OH, J. Y., SONG C. K., JEON, E. J., RYU, H. S., LEE, C. H. 2012. Mass Spectrometry-Based Metabolite Profiling and Bacterial Diversity Characterization of Korean Traditional Meju During Fermentation. J. Microbiol. Biotechnol., 22(11), 1523-1531. http://dx.doi.org/10.4014/jmb.1207.07003

NAMRATA, T., PAL, J., TAMANG, J. P. 2004. Microbial Diversity in Ngari, Hentak and Tungtap, Fermented Fish Products of North-East India. World Journal of Microbiology and Biotechnology, Volume 20, Number 6, 599-607(9). http://dx. doi.org/ 10.1023/B:WIBI.0000043171.91027.7e

NASCIMENTO, W.C.A., MARTINS, M.L.L. 2004. Production and properties of an extracellular protease from thermophilic Bacillus sp. Brazilian Journal of Microbiology, 35, 91-96. ISSN 1517-8382

OJINNAKA M.T. C., OJIMELUKWE, P. C. 2013. Study of the Volatile Compounds and Amino Acid Profile in Bacillus Fermented Castor Oil Bean Condiment. Journal of Food Research, 2, 1. doi:10.5539/jfr.v2n1p191. http://dx.doi.org/10.5539/jfr.v2n1p19

OYEWOLE, O.A. AND ISAH, P. 2012. Locally Fermented Foods in Nigeria and their Significance to National Economy: a Review. J Rec Adv Agri, 1(4): 92-102. QIN, L., \& DING, X. 2007. Formation of taste and odour compounds during preparation of douchiba, a Chinese traditional soy-fermented appetizer. J. Food Biochem., 31, 230-251. http://dx. doi.org/ 10.1111/j.1745-4514.2007.00105.x QURESHI, A., ITANKAR. Y., OJHA. R., MANDAL, M., KHARDENAVIS, A., KAPLEY. A., PUROHIT. H.J. 2014. Genome Sequence of Probiotic Lactobacillus plantarum EGD-AQ4, Genome Announcement, January/February, 2, Issue $1 \mathrm{e} 01122.13$

SANNI, A.A.I., MORLON-GUYOT, J., GUYOT, J.P. 2002. New efficient amylase-producing strains of Lactobacillus plantarum and L. fermentum isolated from different Nigerian traditional fermented foods. International Journal of Food Microbiology, 72, 53-62.

STEINHAUS, P., \& SCHIEBERLE, P. 2007. Characterization of the key aroma compounds in soy sauce using approaches of molecular sensory science. J. Agric. Food Chem., 55, 6262-6269.

TAMANG, B., TAMANG , J. P., SCHILLINGER, U., FRANZ, C.M.A.P. GORES, M., HOLZAPFEL, W. H. 2008. Phenotypic and genotypic identification of lactic acid bacteria isolated from ethnic fermented bamboo tender shoots of North East India. International Journal of Food Microbiology, 15; 121, 35-40.

TAMANG, J. P., TAMANG, N., THAPA, S., DEWAN, S., TAMANG, B. YONZAN, H., RAI, A. K., CHETTRI, R., CHAKRABARTY, J., \& KHAREL N. 2012. Microorganisms and Nutritional value of Ethnic fermented foods and alcoholic beverages of North East India. Indian Journal of Traditional Knowledge, 11, 1

TAMURA, K., PETERSON, D., PETERSON, N., STECHER, G., NEI, M., AND KUMAR, S. 2011. MEGA5: Molecular Evolutionary Genetics Analysis using Maximum Likelihood, Evolutionary Distance, and Maximum Parsimony Methods, Molecular Biology and Evolution 28: 2731-2739. http://dx. doi.org/ 10.1093/molbev/msr121.

THAPA, N., PAL, J., TAMANG, J.P. 2006. Phenotypic identification and technological properties of lactic acid bacteria isolated from traditionally processed fish products of the Eastern Himalayas. International Journal of Food Microbiology, $107, \quad$ pp. $33-38 . \quad \underline{\text { htp://dx }}$ doi.org/ 10.1016/j.ijfoodmicro.2005.08.009

THOMPSON, J.D., GIBSON, T.J., PLEWNIAK, F., JEANMOUGIN, F. HIGGINS, D.G. 1997. The CLUSTAL_X windows interface: flexible strategies for multiple sequence alignment aided by quality analysis tools. Nucleic Acids Res., 25, 4876-4882. 